\title{
Front Matter: Volume 11599
}

, "Front Matter: Volume 11599," Proc. SPIE 11599, Medical Imaging 2021: Image Perception, Observer Performance, and Technology Assessment, 1159901 (12 April 2021); doi: 10.1117/12.2595462

SPIE. Event: SPIE Medical Imaging, 2021, Online Only 


\title{
PROGRESS IN BIOMEDICAL OPTICS AND IMAGING
}

\section{Medical Imaging 2021}

\section{Image Perception, Observer Performance, and Technology Assessment}

\author{
Frank W. Samuelson \\ Sian Taylor-Phillips \\ Editors
}

\section{5-19 February 2021 \\ Online Only, United States}

Sponsored by

SPIE

Cooperating Organizations

AAPM-American Association of Physicists in Medicine (United States)

MIPS-Medical Image Perception Society (United States)

SIIM-Society for Imaging Informatics in Medicine (United States)

WMIS - World Molecular Imaging Society (United States)

Published by

SPIE 
The papers in this volume were part of the technical conference cited on the cover and title page. Papers were selected and subject to review by the editors and conference program committee. Some conference presentations may not be available for publication. Additional papers and presentation recordings may be available online in the SPIE Digital Library at SPIEDigitalLibrary.org.

The papers reflect the work and thoughts of the authors and are published herein as submitted. The publisher is not responsible for the validity of the information or for any outcomes resulting from reliance thereon.

Please use the following format to cite material from these proceedings:

Author(s), "Title of Paper," in Medical Imaging 2021: Image Perception, Observer Performance, and Technology Assessment, edited by Frank W. Samuelson, Sian Taylor-Phillips, Proceedings of SPIE Vol. 11599 (SPIE, Bellingham, WA, 2021) Seven-digit Article CID Number.

ISSN: 1605-7422

ISSN: $2410-9045$ (electronic)

ISBN: 9781510640276

ISBN: 9781510640283 (electronic)

Published by

SPIE

P.O. Box 10, Bellingham, Washington 98227-0010 USA

Telephone +1 3606763290 (Pacific Time) · Fax + 13606471445

SPIE.org

Copyright @ 2021, Society of Photo-Optical Instrumentation Engineers.

Copying of material in this book for internal or personal use, or for the internal or personal use of specific clients, beyond the fair use provisions granted by the U.S. Copyright Law is authorized by SPIE subject to payment of copying fees. The Transactional Reporting Service base fee for this volume is $\$ 21.00$ per article (or portion thereof), which should be paid directly to the Copyright Clearance Center (CCC), 222 Rosewood Drive, Danvers, MA 01923. Payment may also be made electronically through CCC Online at copyright.com. Other copying for republication, resale, advertising or promotion, or any form of systematic or multiple reproduction of any material in this book is prohibited except with permission in writing from the publisher. The CCC fee code is 1605$7422 / 21 / \$ 21.00$.

Printed in the United States of America by Curran Associates, Inc., under license from SPIE.

Publication of record for individual papers is online in the SPIE Digital Library.

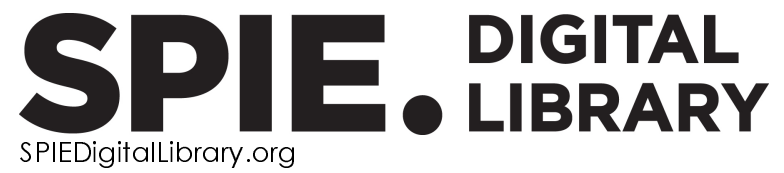

Paper Numbering: Proceedings of SPIE follow an e-First publication model. A unique citation identifier (CID) number is assigned to each article at the time of publication. Utilization of CIDs allows articles to be fully citable as soon as they are published online, and connects the same identifier to all online and print versions of the publication. SPIE uses a seven-digit CID article numbering system structured as follows:

- The first five digits correspond to the SPIE volume number.

- The last two digits indicate publication order within the volume using a Base 36 numbering system employing both numerals and letters. These two-number sets start with $00,01,02,03,04$, 05, 06, 07, 08, 09, OA, OB ... 0Z, followed by 10-1Z, 20-2Z, etc. The CID Number appears on each page of the manuscript. 


\section{Contents}

MODALITY-SPECIFIC ASSESSMENT METHODS

1159904 Task-based assessment of binned and list-mode SPECT systems [1 1599-1]

1159905 Observer study-based evaluation of a stochastic and physics-based method to generate oncological PET images [1 1599-2]

1159906 Spatiotemporal characteristics of medical extended-reality systems [1 1599-3]

1159907 Grayscale contrast enhancement based on greyscale-based contrast-to-noise ratio [1 1599-4]

1159908 Towards the objective assessment of fluoroscopy systems: development of a framework to aid the design of tasks and metrics [1 1599-5]

$1159909 \quad$ Limitation of acyclic oriented graphs matching as cell tracking accuracy measure when evaluating mitosis [1 $1599-6]$

MODEL OBSERVERS I

11599 OA Advancing the AmbientGAN for learning stochastic object models [1 1599-7]

11599 OB CNN based anthropomorphic model observer for defect localization [1 1599-8]

11599 OC Understanding CNN based anthropomorphic model observer using classification images [11599-9]

11599 OD A hybrid channelized Hotelling observer for estimating the ideal linear observer for totalvariation-based image reconstruction [1 1599-10]

11599 OE Implementation of CNN-based multi-slice model observer for 3D cone beam CT [1 $1599-11]$

MODEL OBSERVERS II

11599 OF Supervised learning-based ideal observer approximation for joint detection and estimation tasks [11599-12]

11599 OG GAN generated model observer for one class detection in SPECT imaging [1 1599-13] 
$11599 \mathrm{OH} \quad$ Modeling human observer detection in undersampled magnetic resonance imaging (MRI) [11599-14]

11599 ol Observer models utilizing compressed textures [1 1599-15]

\section{ARTIFICIAL INTELLIGENCE}

11599 0J Effect of CAD system with a vessel suppression function on clinical lung nodule detection in chest CT scans [11599-17]

11599 OK An end-to-end deep learning model can detect the gist of the abnormal in prior mammograms as perceived by experienced radiologists [11599-18]

$11599 \mathrm{OL} \quad$ Task-based performance evaluation of deep neural network-based image denoising [11599-19]

11599 OM Towards a quantitative analysis of class activation mapping for deep learning-based computer-aided diagnosis [1 1599-20]

11599 ON Assessing regularization in tomographic imaging via hallucinations in the null space [11599-21]

1159900 Comparison of diagnostic performances, case-based repeatability, and operating sensitivity and specificity in classification of breast lesions using DCE-MRI [1 1599-22]

\section{OBSERVER PERFORMANCE EVALUATION AND ROC}

11599 OP The perceptual influence of 2D synthesized images on 3D search [1 1599-16]

$115990 Q \quad$ Test set participation may impact positively on clinical mammographic performance [1 1599-23]

11599 OR Effect of time awake and hours slept at night on radiologists' interpretations of mammogram images [1 1599-24]

11599 OS Blink identification with eye tracking: a software processing program [1 1599-25]

11599 OT Employing eye tracking to identify the onset of fatigue in Digital Breast Tomosynthesis (DBT) readers for a national breast cancer screening programme [11599-26]

11599 OU A retrospective comparative study of reading performances between radiologists from two countries in the assessment of 3D mammography [1 1599-27] 
11599 0X Task-based evaluation of deep image super-resolution in medical imaging (Cum Laude Poster Award) [11599-30]

11599 OY Learning observer design for object detection under complex background and variant locations: an application in IQ assessment with spectrum shaping technique for ultra-low dose lung imaging [1 1599-31]

$115990 Z$ Class classification using two alternate force choice against an ensemble of normal examples [11599-32] 
Proc. of SPIE Vol. 11599 1159901-6

Downloaded From: https://www.spiedigitallibrary.org/conference-proceedings-of-spie on 26 Apr 2023
Terms of Use: https://www.spiedigitallibrary.org/terms-of-use 